\title{
Demographic Characteristics of Mirik Municipality with Reference to 2001 \& 2011 Census Data
}

\author{
Ershad Ali* \\ *Corresponding Author: Ershad Ali, Guest Lecturer, Department of Geography, Ananda Chandra \\ College, Jalpaiguri, West Bengal, India
}

\begin{abstract}
In the Mirik Municipality, there lies a demographical spatial variation in the distribution, density, composition, sex-ratio, literacy rate, and the growth of population which has a direct impact on the utilization of resources and the development of the town. The distribution pattern, density, composition, growth rate and migration therefore adds important attributes to the demography of Mirik Municipality and is controlled by physical, cultural, political and socio-economic factors. However, due to rapid growth of population, urbanization, and tourist activities, the Mirik municipality is getting stressed with its carrying capacity. Thus, the paper has an attempt to study the demographical status of the Mirik Municipality highlighting its present situation.
\end{abstract}

Keywords: Mirik, Demography, Effective Literacy rate, Population Density, Urban Slum.

\section{INTRODUCTION}

The word Demography is derived from two Greek words "demo" meaning population and "graphy" meaning study. Hence, the study of population is termed as "Demography". The word Demography was first used by French writer Achille Guillard in 1855. But the father of Demography is John Graunt. Demography is of recent systematic study of development like the science of sociology. According to D.J Bougue "Demography is a statistical and mathematical study of the size, composition, spatial distribution of human population and of changes overtime in these aspects through the operation of the five processes of fertility, mortality, marriage, migration, and social mobility. According to U.N Multilingual Demographic Dictionary, it is the scientific study of the human development.

\section{OBJECTIVES}

Objectives behind the field study are:

- To study the demographic characteristics of Mirik Municipality.

- To find out the different problems related to the demographic characteristics of the Mirik Municipality.

\section{STUDY AREA}

The name Mirik comes from the Lepcha words Mir-Yok meaning "place burnt by fire". Mirik Municipality with agreement between Sate Govt. and Private Tea Company this Municipality was agglomerated, consisting of 9 wards. Mirik Municipality is situated on the Kurseong Sub-division of Darjeeling District in the hilly area of Sikkim-Darjeeling Himalayas. Geographically, it is located from $26^{\circ} 54^{\prime} \mathrm{N}$ to $26^{\circ} 57^{\prime} \mathrm{N}$ and from $88^{\circ} 10^{\prime} \mathrm{E}$ to $88^{\circ} 13^{\prime} \mathrm{E}$.

\section{Data Base \& Methodology}

In order to study the demographic characteristics of the study area, the methodology adopted by the present investigator is a rationalistic one comprising of the details outlined as follows:-

The demographic information regarding growth of population, age-sex composition, population density, male-female distribution etc samples have been collected from different primary and 
secondary sources. The data has been analyzed by using different statistical and mathematical formulas and also by interpreting the primary and secondary data like-

ELR $=\frac{\text { Number of Literate persons aged } 7 \text { and above }}{\text { Population aged } 7 \text { and above }} * 100$; Mean etc. Diagrams have been prepared on Microsoft Office Excel 2007 and maps on GIS software like Global Mapper and MapInfo software.

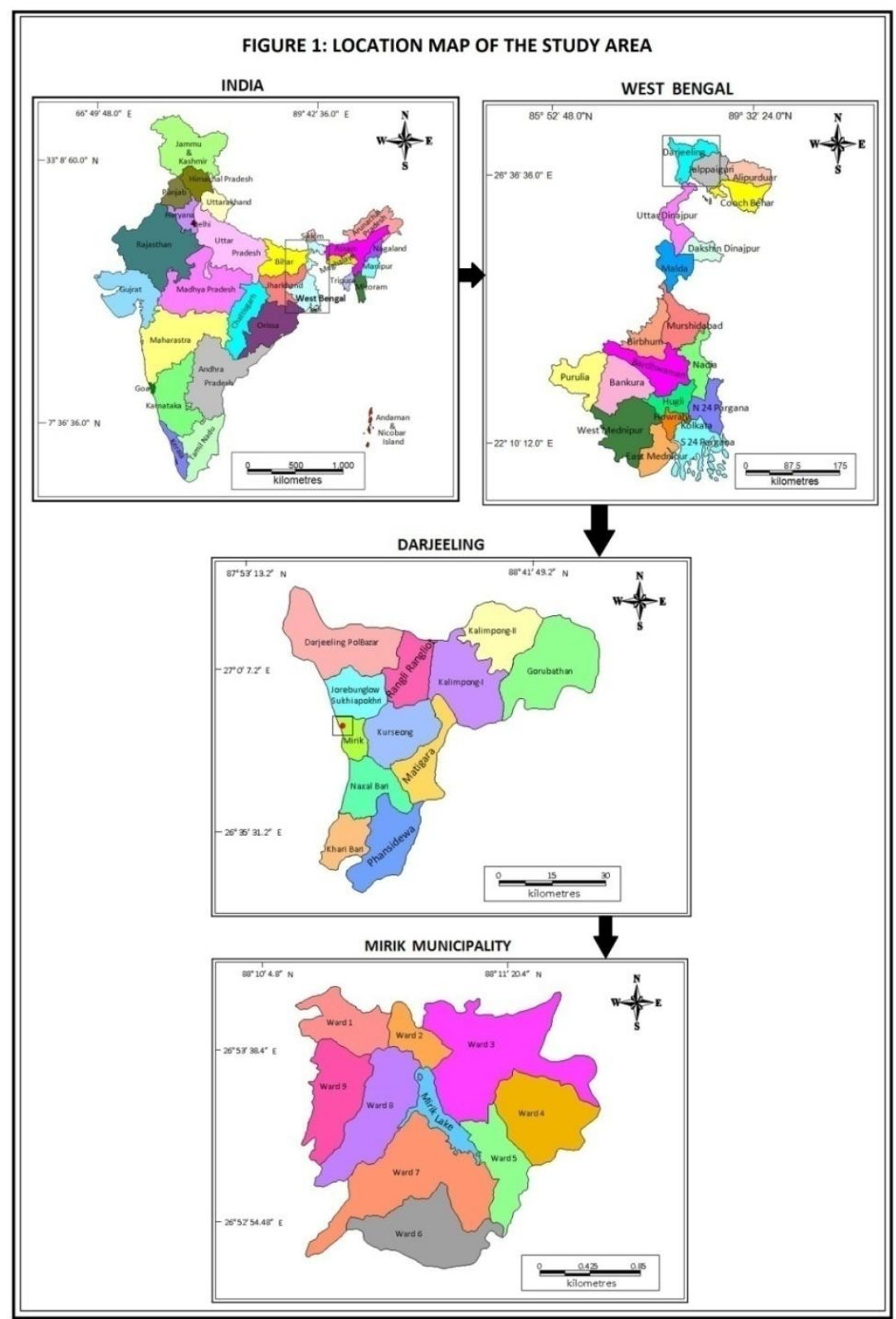

Source: Mirik Municipality

\section{RESUltS AND DiSCUSSION}

The following demographical characteristics are noticed in Mirik Municipality through the Census of $2001 \& 2011$.

\subsection{Growth of Population}

According to 2011 census, the Mirik Municipality has a population of 11513 (out of this 5688 were male and 5825 were female) which was 9112 in 2001 census. Therefore, the growth rate of population is $(+) 20.85 \%$.

If we look at the ward-wise decadal growth of the Mirik Municipality then we will find that except ward 2 , every ward $(1,3,4,5,6,7,8$, and 9$)$ has a trend of positive growth rate between the year of 2001 and 2011. Only ward no. 2 shows a negative growth rate. 
Demographic Characteristics of Mirik Municipality with Reference to 2001 \& 2011 Census Data

Table1: ward-wise decadal growth rate of population in Mirik Municipality, 2001 \& 2011

\begin{tabular}{|l|l|l|l|}
\hline Ward Number & Population in 2001 & Population in 2011 & Decadal Growth rate in \% \\
\hline 1 & 831 & 1113 & 25.34 \\
\hline 2 & 1414 & 1247 & -13.39 \\
\hline 3 & 1421 & 1516 & 6.27 \\
\hline 4 & 772 & 1096 & 29.56 \\
\hline 5 & 591 & 857 & 31.04 \\
\hline 6 & 720 & 982 & 26.68 \\
\hline 7 & 1032 & 1319 & 21.76 \\
\hline 8 & 1270 & 1856 & 31.57 \\
\hline 9 & 1090 & 1176 & 7.31 \\
\hline
\end{tabular}

Source: Census of $2001 \& 2011$

FIGURE 2: WARD-WISE DECADAL GROWTH RATE OF POPULATION IN MIRIK MUNICIPALITY(2001-2011)

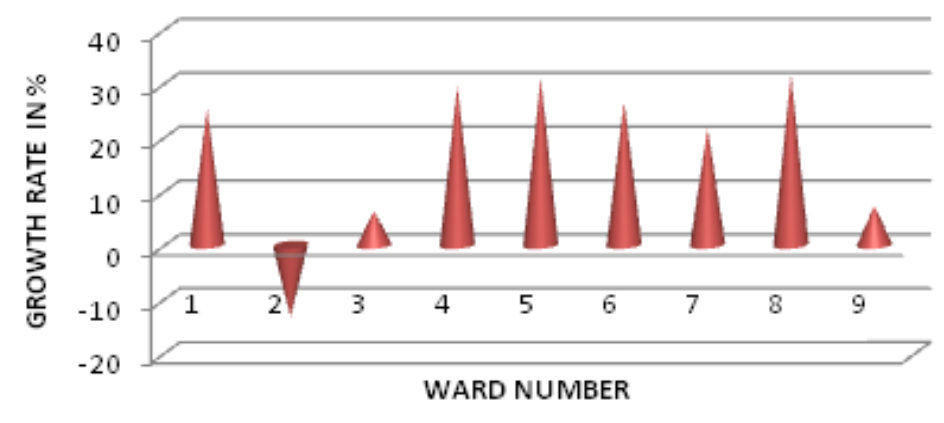

INDEX

Decadal Growth rate in \%

FIGURE 3: WARD-WISE DECADAL TREND OF POPULATION IN MIRIK MUNICIPALITY (2001-2011)

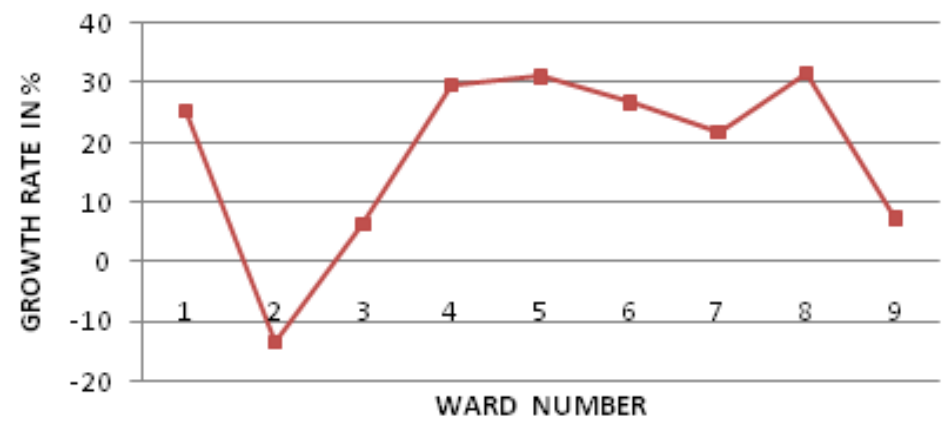

INDEX

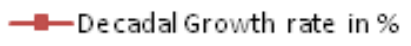

If we look at the ward-wise decadal growth rate of Mirik Municipality, then we will find that ward number $1,3,4,5,6,7,8$ and 9 has a positive growth rate. The highest growth rate of population is found in ward number $8(31.57 \%)$, followed by ward number $5(31.04 \%), 4(29.56 \%), 6(26.68 \%), 1$ $(25.34 \%), 7(21.76 \%), 9(7.31 \%),(6.27 \%)$. Besides this, a negative growth rate of population is found in ward number $2(-13.39 \%)$. From a primary sample survey, it is found that mainly due to outmigration the population of ward number 2 is declining.

\subsection{Population Density}

Density of population is a better measure of understanding the variation in the distribution of population. It is expressed as number of persons per unit area. According to 2001 census, the population density of Mirik Municipality was 1862 persons/sq.km which rises to 2154 persons/sq. km in 2011 i.e. 292 persons were added in one decade for all wards. In case of plain area town that kind of density is taken into consideration as low density but due to its hilly location, this density come under moderate terms. Though all wards are moderately densed but in my discussion I have divided 
the Municipal area into 4 density zones (according to the population density classification of R.C.Chandana). These are High density zone, Moderate density zone, Low density zone and Very low density zone.

- Very High Density Zone (>2000 persons/sq.km): In 2001, only 1 ward belonged to this category, i.e., ward number 2 with 5860 persons/sq.km.

- High Density Zone (1500-2000 persons/sq.km): 3 wards belonged to this category, i.e., ward number 1(1955 persons/sq.km), 9 (1887 persons/sq.km) and 8 (1726 persons/sq.km).

- Moderate Density Zone (1000-1500 persons/sq.km): 3 wards belonged to this category, i.e., ward number 5 (1326 persons/sq.km), 4 (1075 persons/sq.km) and 3 (1072 persons/sq.km).

- Low Density Zone ( $<\mathbf{1 0 0 0}$ persons/sq.km): 2 wards belonged to this category. Those were 6 (977 persons/sq.km) and 7 (876 persons/sq.km).

Table2: Ward-Wise Population Density of Mirik Municipality in 2001 \& 2011

\begin{tabular}{|l|l|l|l|l|l|}
\hline Ward No. & Area $\left(\mathrm{km}^{2)}\right.$ & $\begin{array}{l}\text { Population in } \\
2001\end{array}$ & $\begin{array}{l}\text { Density in 2001 } \\
\left(\text { per km }^{2)}\right.\end{array}$ & $\begin{array}{l}\text { Population in } \\
2011\end{array}$ & $\begin{array}{l}\text { Density in 2011 } \\
(\text { per km }\end{array}$ \\
\hline 1 & 0.43 & 831 & 1955 & 1113 & 2619 \\
\hline 2 & 0.24 & 1414 & 5860 & 1247 & 5166 \\
\hline 3 & 1.33 & 1421 & 1072 & 1516 & 1144 \\
\hline 4 & 0.72 & 772 & 1075 & 1096 & 1527 \\
\hline 5 & 0.45 & 591 & 1326 & 857 & 1922 \\
\hline 6 & 0.74 & 720 & 977 & 982 & 1333 \\
\hline 7 & 1.18 & 1032 & 876 & 1319 & 1120 \\
\hline 8 & 0.74 & 1270 & 1726 & 1856 & 2522 \\
\hline 9 & 0.58 & 1090 & 1887 & 1176 & 2036 \\
\hline
\end{tabular}

Source: Census of 2001 and 2011

\subsubsection{Density Distribution in 2011}

In 2011 population densities, it was again classified into 4 categories (according to the population density classification of R.C.Chandana). These are High density zone, Moderate density zone, Low density zone and Very low density zone.

- Very High Density Zone (>2500 persons/sq.km): In 2011, 3 wards belong to this category. These are ward number 2 (5166 persons/sq.km), 1 (2619 persons/sq.km) and 8 (2522 persons/sq.km).

- High Density Zone (2000-2500 persons/sq.km): Only one ward belongs to this category that is ward number 9 (2036persons/sq.km).

- Moderate Density Zone (1500-2000 persons/sq.km): Here 2 wards come in this category. Those are ward number 5 (1922 persons/sq.km) and 4 (1527 persons/sq.km).

- Low Density Zone (<1500 persons/sq.km): 3 wards belong to this category, i.e., ward number 6 (1333 persons/sq.km), 3 (1144 persons/sq.km) and 7 (1120 persons/sq.km).

\subsubsection{Variation of Density and its Reason in Different wards}

With the help of 2001 and 2011 census I had divided the whole Municipality wards into 4 density zones. In 2001, only 1 ward had very high density (ward 2) but in 2011 the number of wards increased under this category also with a hike in the density. The wards are 2,1 and 8 . This is very high density area because this area is more homogeneous than other part of the respective area and also having a commercial market. So this portion is more congested than other part.

The second zone also consists of high density zone which comprises the ward number 9. This is purely residential area.

$3^{\text {rd }}$ zone includes the wards of 4 and 5 . This zone is moderately dense because of medical facilities, playground, health, school and marketing accessibilities in this area.

The last density zone comprises the area of ward number of 3,6 and 7. This portion of the Municipality is more undulating area than any other part. Due to its hilly slope and inadequate supply 
of daily essential commodities, large portion is occupied with open space, having low-lying areas; inadequacy of school and college and marketing facilities are the main causes for low density.

One thing is important here that except the ward number 2, all other ward has increased its density size. Though the ward number 2 has consistently occupied its first position on density of population but the size of the density has decreased. In 2001 the density size was 5860 persons/sq.km but in 2011 the density size has decreased to 5166 persons/sq.km i.e. 694 persons/sq.km decreased.

FIGURE 4: WARD-WISE POPULATION DENSITY MAP OF MIRIK MUNICIPALITY IN 2001

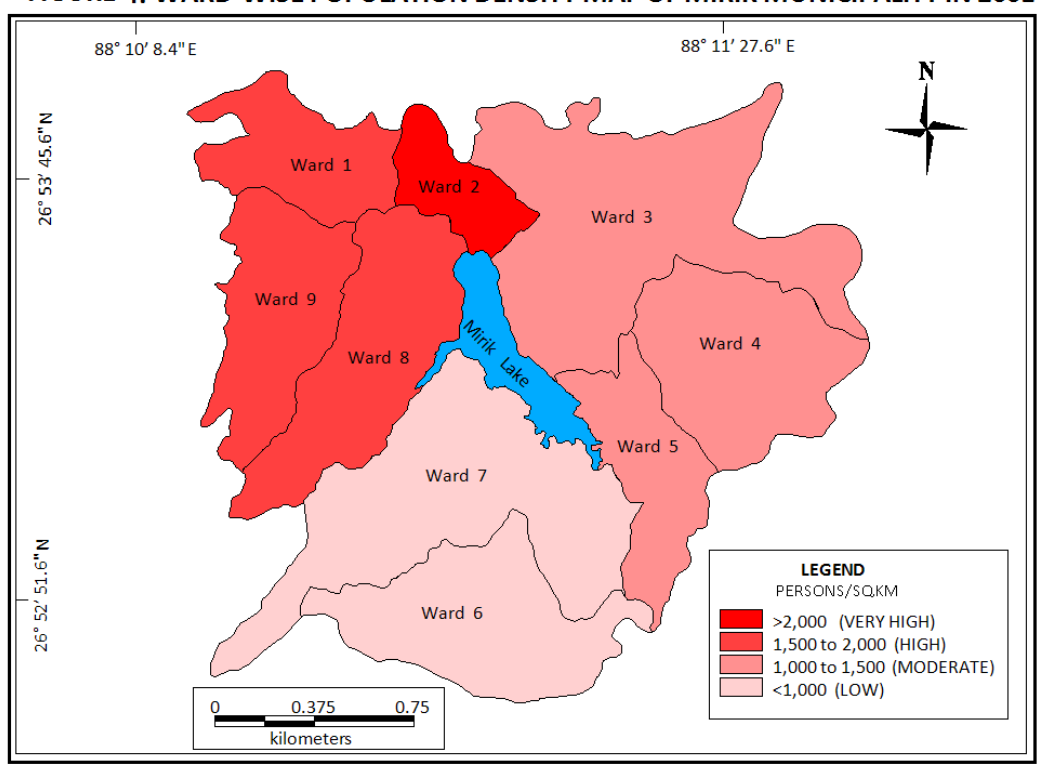

FIGURE 5: WARD-WISE POPULATION DENSITY MAP OF MIRIK MUNICIPALITY IN 2011

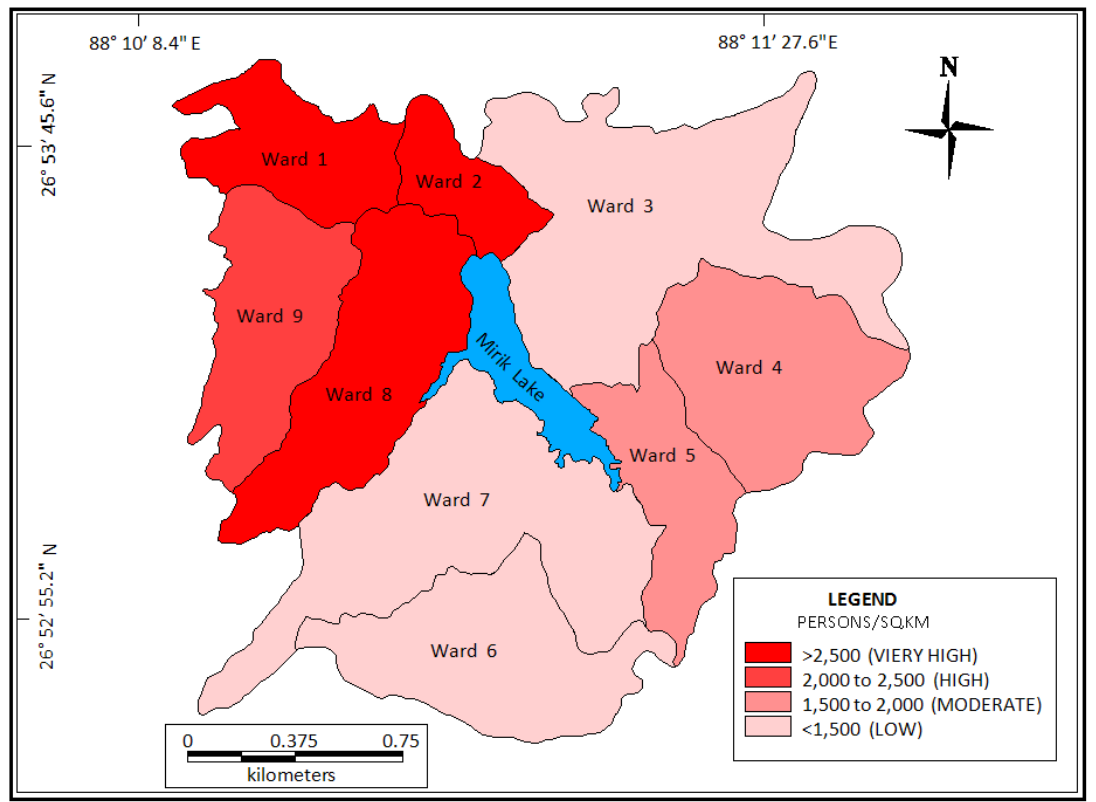

Source: Mirik Municipality

\subsection{Male-Female Distribution}

In 2001 census, the total population of Mirik Municipality was 9112, out of which 4582 were male and 4530 were female. The highest population found in ward number 3 was 1420 and the lowest population found in ward 5 was 600 . The highest male population found in ward number 3 was 726 and lowest male population found in ward number 5 was 294. The highest female population found in ward number 3 was 694 and lowest female population found in ward number 5 was 306.

But in 2011 census, the total population of Mirik Municipality was 11513, out of which 5688 were male and 5825 were female. The highest population was found in ward number 3 which was 1824 and 
the lowest population was found in ward 6 which was 859 . The highest male was population found in ward number 3 which was 906 and lowest male population was found in ward number 6 which was 416. The highest female population was found in ward number 3 which was 918 and lowest female population was found in ward number 6 which was 443.

Table3: Number of Male-Female Population in Mirik Municipality, 2001 \& 2011

\begin{tabular}{|l|l|l|l|}
\hline Ward No & Male & Female & Total \\
\hline 1 & 377 & 410 & 787 \\
\hline 2 & 719 & 690 & 1409 \\
\hline 3 & 726 & 694 & 1420 \\
\hline 4 & 380 & 372 & 752 \\
\hline 5 & 294 & 306 & 600 \\
\hline 6 & 388 & 334 & 722 \\
\hline 7 & 528 & 534 & 1062 \\
\hline 8 & 629 & 641 & 1270 \\
\hline 9 & 541 & 549 & 1090 \\
\hline Total & $\mathbf{4 5 8 2}$ & $\mathbf{4 5 3 0}$ & $\mathbf{9 1 1 2}$ \\
\hline
\end{tabular}

\begin{tabular}{|l|l|l|l|}
\hline Ward No & Male & Female & Total \\
\hline 1 & 439 & 465 & 904 \\
\hline 2 & 748 & 818 & 1566 \\
\hline 3 & 906 & 918 & 1824 \\
\hline 4 & 722 & 588 & 1310 \\
\hline 5 & 441 & 521 & 962 \\
\hline 6 & 416 & 443 & 859 \\
\hline 7 & 642 & 642 & 1284 \\
\hline 8 & 805 & 833 & 1638 \\
\hline 9 & 569 & 597 & 1166 \\
\hline Total & $\mathbf{5 6 8 8}$ & $\mathbf{5 8 2 5}$ & $\mathbf{1 1 5 1 3}$ \\
\hline
\end{tabular}

Source: Census of $2001 \& 2011$

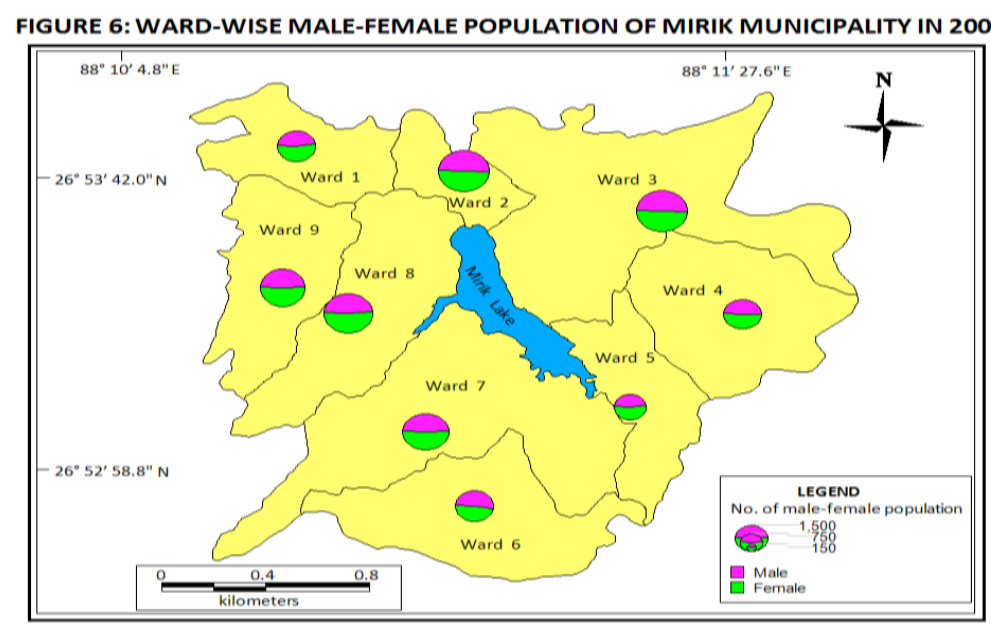

FIGURE 7: WARD-WISE MALE-FEMALE POPULATION OF MIRIK MUNICIPALITY IN 2011

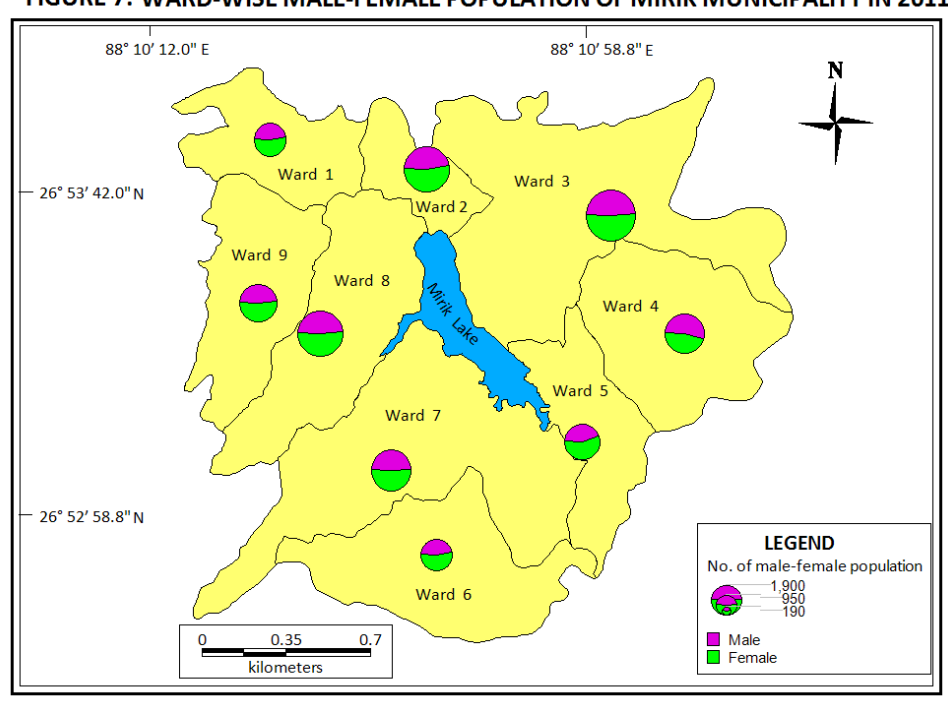

Source: Mirik Municipality

\subsection{Sex-Ratio}

Sex ratio indicates the number of female per thousand male. In 2001 census the highest sex ratio of Mirik Municipality found in ward number 1 was 1088 (377 were male and 410 were female) and the lowest sex ratio was found in ward number 6 which was 861 (388 were male and 334 were female). It shows that the difference between highest and lowest sex ratio of Mirik Municipality in 2001 is 
$(1088-861)=227$. In 2001, the above 1000 sex ratio found in ward number 5 (1041), 8 (1019), 9 (1015), 7 (1011) and below 1000 sex ratio found in ward number 4 (979), 2 (960), 3 (956), and 6 (861).

But 2011 census shows that the highest sex ratio of Mirik Municipality is in the ward number of 5 which is 1181 (441 are male and 521 are female). In 2001 that number was 1041 i.e. (1181-1041) = 140 i.e. $11.9 \%$ increased. The lowest sex ratio was found in ward number 4 which was 814 (722 are male and 588 are female) but in 2001 that number was 979 which indicates $(979-814=165) 16.9 \%$ decrease. Except ward number 4, all the other wards had the sex ratio above 1000, this are 5 (1181), 2 (1094), 6 (1065), 1 (1059), 9 (1049), 8 (1035), 3 (1013), 7 (1000).

Table4: Ward-Wise Sex-Ratio of Mirik Municipality, 2001 \& 2011

\begin{tabular}{|l|l|l|l|}
\hline Ward No. & Sex ratio in 2001 & Sex ratio in 2011 & Increase \\
\hline 1 & 1088 & 1059 & -29 \\
\hline 2 & 960 & 1094 & 134 \\
\hline 3 & 956 & 1013 & 57 \\
\hline 4 & 979 & 814 & -165 \\
\hline 5 & 1041 & 1181 & 140 \\
\hline 6 & 861 & 1065 & 204 \\
\hline 7 & 1011 & 1000 & -11 \\
\hline 8 & 1019 & 1035 & 16 \\
\hline 9 & 1015 & 1049 & 34 \\
\hline Total & $\mathbf{9 8 9}$ & $\mathbf{1 0 2 4}$ & $\mathbf{3 5}$ \\
\hline
\end{tabular}

Source: Census of 2001 and 2011.

The overall sex ratio of Mirik Municipality in 2001 was 989 but in 2011 it is 1024 (1024-989) = 35 i.e. a dramatic changes occurred with increasing $3.4 \%$ growth rate. So it is good to see that the female population of Mirik Municipality is increasing and the overall sex-ratio is good for future.
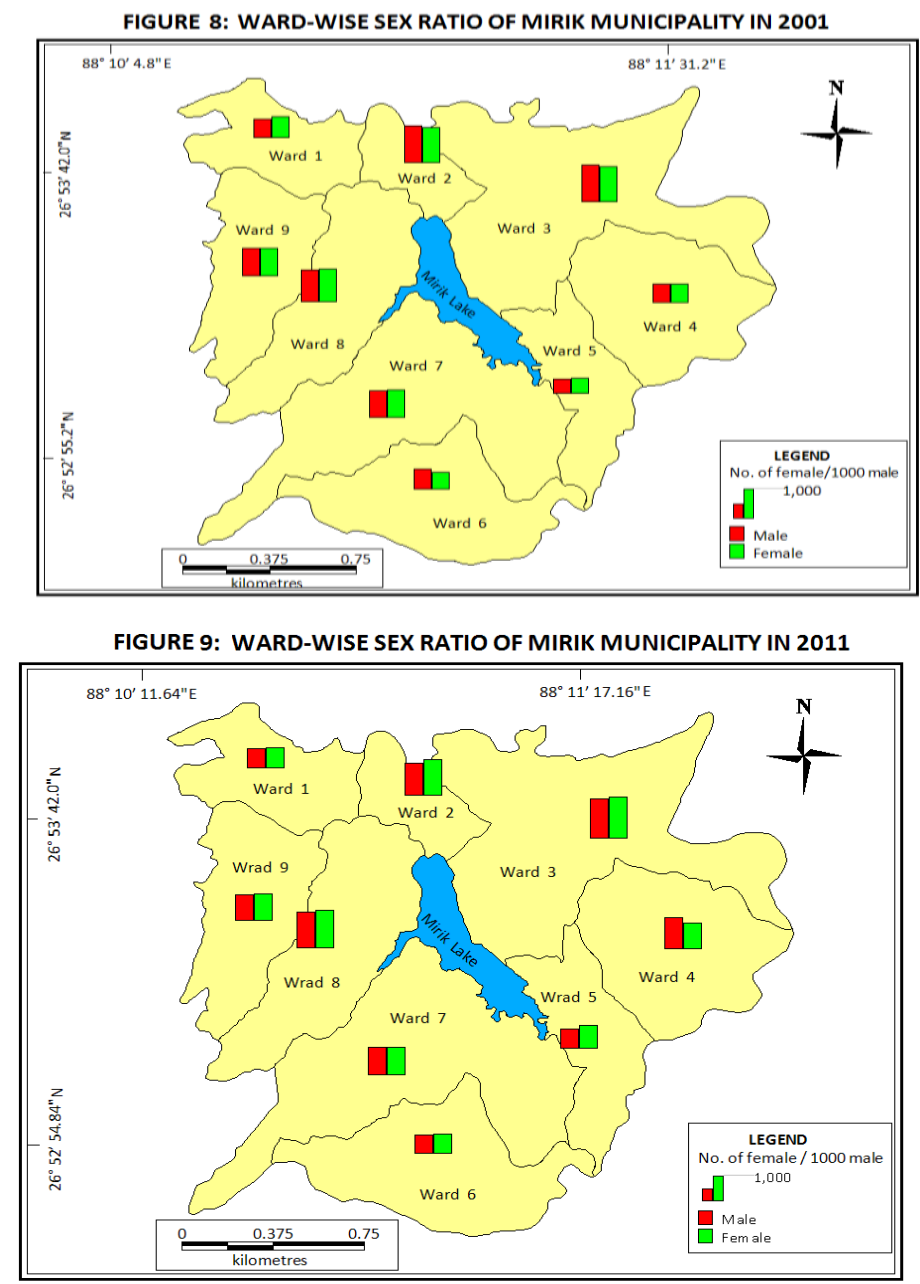

Source: Mirik Municipality 
Besides this, the highest growth rate of sex-ratio found in ward number $6(19.2 \%)$ and the lowest growth rate is in ward number $4(-20.3 \%)$. Except this, some of the ward had a negative growth sexratio and the ward is $1(-2.7 \%), 7(-1.1 \%)$.

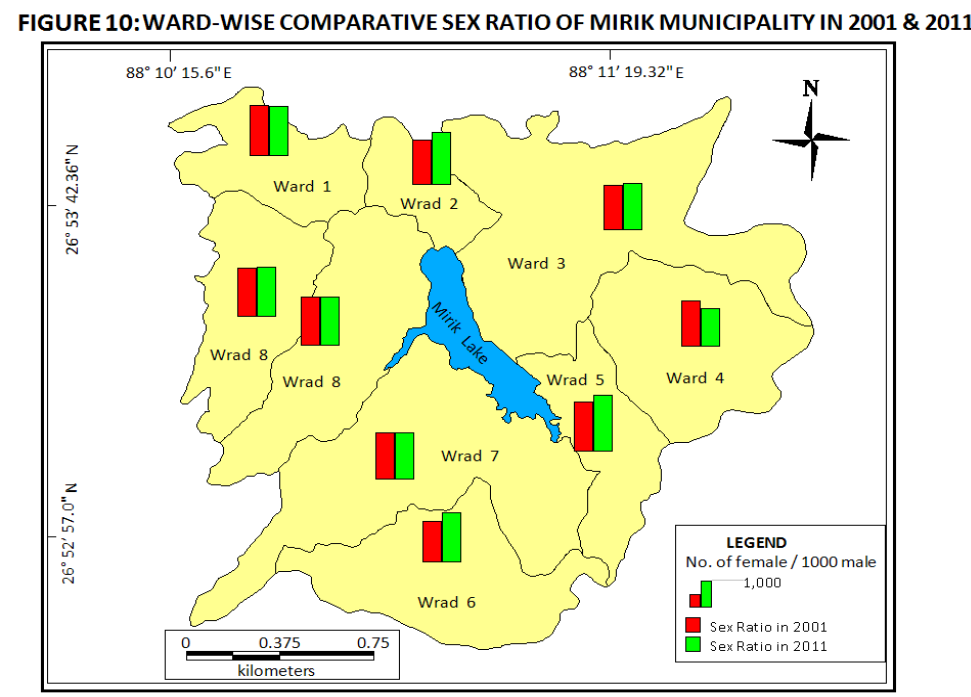

Source: Mirik Municipality

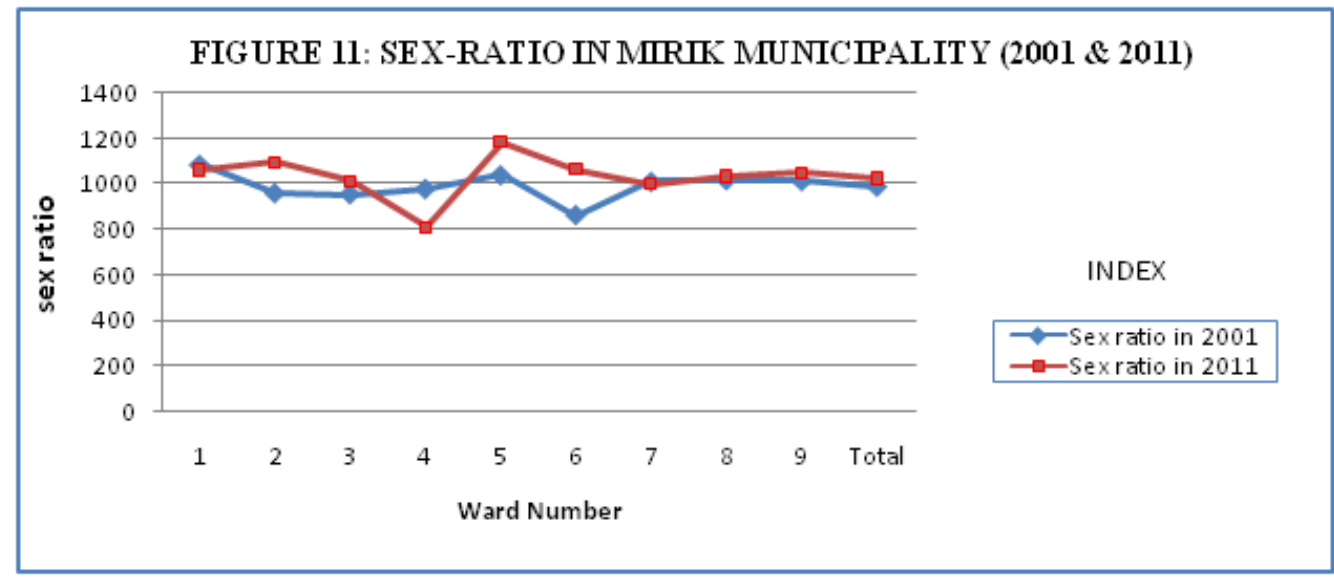

\subsection{Child Population}

According to 2001 census, Mirik Municipality had 858 child populations in $0-6$ years which occupied $9.42 \%$ of total population, 702 child populations in 6-10 years which was $7.70 \%$ of total population, 839 child populations in 10-18 years which was $9.21 \%$ of total population of Mirik town.

Table5: Age of Children in 2001

\begin{tabular}{|l|l|l|}
\hline Age of children & Number of children in 2001 & \% of child population to total population \\
\hline $0-6$ years & 858 & 9.42 \\
\hline 6-10 years & 702 & 7.70 \\
\hline $10-15$ years & 839 & 9.21 \\
\hline
\end{tabular}

Source: Census of 2001

But 2011 census shows that the overall child population scenario had changed. The total child population under the age of 0-6 years is 1098 which is $9.53 \%$ of total population, in 6-10 years there are 900 which are $7.82 \%$ and under $10-18$ years child populations there is 1073 which is $9.32 \%$.

Table6: Age of Children in 2011

\begin{tabular}{|l|l|l|}
\hline Age of children and dependents & Number of children in 2011 & \% of child population to total population \\
\hline $0-6$ years & 1098 & 9.53 \\
\hline $6-10$ years & 900 & 7.82 \\
\hline $10-15$ years & 1073 & 9.32 \\
\hline
\end{tabular}

Source: Census of 2011 
Table7: Growth Rate of Age of Children

\begin{tabular}{|l|l|l|l|}
\hline Age of children & $\begin{array}{l}\text { \% of child population to total } \\
\text { population in 2001 }\end{array}$ & $\begin{array}{l}\text { \% of child population to total } \\
\text { population in 2011 }\end{array}$ & $\begin{array}{l}\text { Growth rate } \\
\text { in \% }\end{array}$ \\
\hline 0-6 years & 9.42 & 9.53 & 0.11 \\
\hline 6-10 years & 7.70 & 7.82 & 0.12 \\
\hline 10-18 years & 9.21 & 9.32 & 0.11 \\
\hline
\end{tabular}

Source: Census of 2001 and 2011

So, there is a static growth rate of child population in Mirik Municipality. The percentage of child population to total population in 2001 and in 2011 follows the same trend (slight growth rate, about $0.11 \%)$.
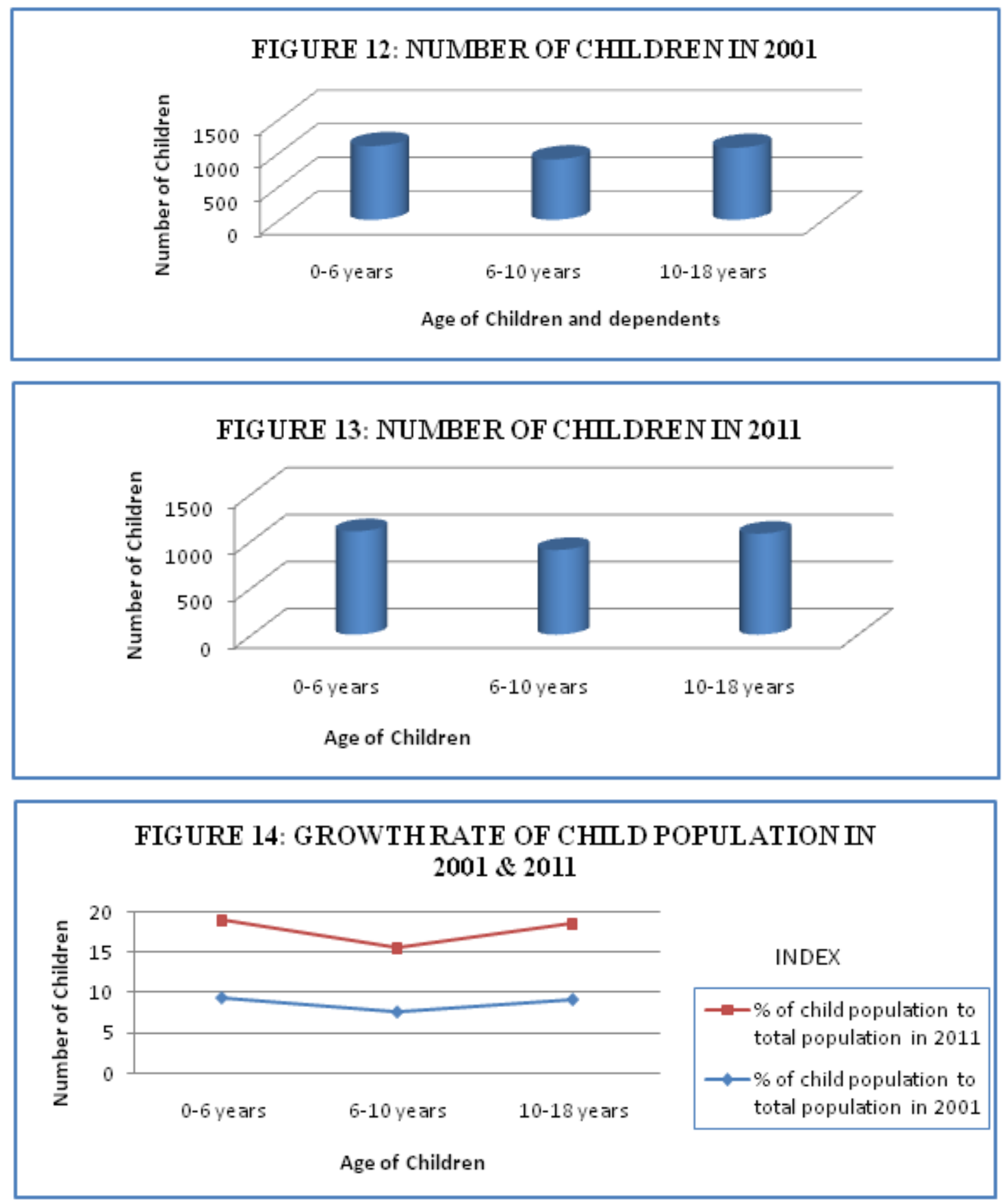

\subsection{Effective Literacy Rate}

The Population Commission of United Nations considers the ability, to both read and write a simple message with understanding in any language, a sufficient basis for classifying a person as literate. According to Census of India, "persons aged seven and above, who can both read and write with 
understanding in any language, is treated as literate". Literacy is essential for eradicating poverty and mental isolation, for cultivating peaceful and friendly international relations in demographic processes. Effective literacy rate has been calculated by the following formula -

$$
\mathrm{ELR}=\frac{\text { Number of Literate persons aged } 7 \text { and above }}{\text { Population aged } 7 \text { and above }} * 100
$$

\subsubsection{Effective Literacy Rate in 2001}

According to provisional census 2001, literacy rate in Mirik Municipality was $73.57 \%$ where male literacy was $81.38 \%$ and female literacy was $65.67 \%$. If we look at the ward wise male and female literacy rate in 2001, then we found that the highest literacy rate in ward number 4 was $87.37 \%$ and the lowest in ward number 6 was $66.34 \%$. Besides this, the highest male literacy found in ward number $4(91.05 \%)$ and lowest was in $7(75.76 \%)$ and the highest female literacy in ward number 4 $(83.60 \%)$ and lowest in ward number $9(57.19 \%)$.

Table8: Ward-Wise \% of Literacy Rate in Mirik Municipality, 2001

\begin{tabular}{|l|l|l|l|l|l|l|l|}
\hline $\begin{array}{l}\text { Ward } \\
\text { No }\end{array}$ & $\begin{array}{l}\text { No. of } \\
\text { Male } \\
\text { literate }\end{array}$ & $\begin{array}{l}\text { No. of } \\
\text { Female } \\
\text { literate }\end{array}$ & $\begin{array}{l}\text { Total } \\
\text { literate }\end{array}$ & $\begin{array}{l}\text { Total } \\
\text { Population }\end{array}$ & $\begin{array}{l}\text { Literacy } \\
\text { Rate In } \\
\text { In }\end{array}$ & $\begin{array}{l}\text { Male } \\
\text { Literacy } \\
\text { Rate In \% }\end{array}$ & $\begin{array}{l}\text { Female } \\
\text { Literacy } \\
\text { In \% }\end{array}$ \\
\hline 1 & 302 & 285 & 587 & 787 & 74.59 & 80.11 & 69.51 \\
\hline 2 & 591 & 496 & 1087 & 1409 & 77.15 & 82.20 & 71.88 \\
\hline 3 & 591 & 448 & 1039 & 1420 & 73.17 & 81.40 & 64.55 \\
\hline 4 & 346 & 311 & 657 & 752 & 87.37 & 91.05 & 83.60 \\
\hline 5 & 260 & 243 & 503 & 600 & 83.83 & 88.44 & 79.41 \\
\hline 6 & 307 & 172 & 479 & 722 & 66.34 & 79.12 & 51.50 \\
\hline 7 & 400 & 309 & 709 & 1062 & 66.76 & 75.76 & 57.87 \\
\hline 8 & 511 & 397 & 908 & 1270 & 71.50 & 81.24 & 61.93 \\
\hline 9 & 421 & 314 & 735 & 1090 & 67.43 & 77.82 & 57.19 \\
\hline Total & 3729 & 2975 & 6704 & 9112 & 73.57 & 81.38 & 65.67 \\
\hline
\end{tabular}

Source: Census of 2001

But in 2011 census, the literacy rate in Mirik Municipality is $81.59 \%$ where male literacy is $86.52 \%$ and female literacy are $76.79 \%$. In 2011, the highest literacy found in ward number 4 is $91.45 \%$ and the lowest literacy rate found in ward number 6 is $71.25 \%$. The highest male literacy is found in ward number $4(93.35 \%)$ and the lowest is found in $9(65.83 \%)$. Similarly, the highest female literate found in ward number $4(89.12 \%)$ and lowest on ward number $9(65.83 \%)$. So the overall literacy rate of Mirik Notified area is high against state rate.

Table9: Ward-Wise \% of Literacy Rate in Mirik Municipality, 2011

\begin{tabular}{|l|l|l|l|l|l|l|l|}
\hline $\begin{array}{l}\text { Ward } \\
\text { No }\end{array}$ & $\begin{array}{l}\text { No. of } \\
\text { Male } \\
\text { literate }\end{array}$ & $\begin{array}{l}\text { No. of } \\
\text { Female } \\
\text { literate }\end{array}$ & $\begin{array}{l}\text { Total } \\
\text { literate }\end{array}$ & $\begin{array}{l}\text { Total } \\
\text { Population }\end{array}$ & $\begin{array}{l}\text { Literacy } \\
\text { Rate In } \\
\text { In }\end{array}$ & $\begin{array}{l}\text { Male } \\
\text { Literacy } \\
\text { Rate In \% }\end{array}$ & $\begin{array}{l}\text { Female } \\
\text { Literacy } \\
\text { In \% }\end{array}$ \\
\hline 1 & 372 & 357 & 729 & 904 & 80.64 & 84.74 & 76.77 \\
\hline 2 & 661 & 680 & 1341 & 1566 & 85.63 & 88.37 & 83.13 \\
\hline 3 & 812 & 732 & 1544 & 1824 & 84.65 & 89.62 & 79.74 \\
\hline 4 & 674 & 524 & 1198 & 1310 & 91.45 & 93.35 & 89.12 \\
\hline 5 & 394 & 455 & 849 & 962 & 88.25 & 89.34 & 87.33 \\
\hline 6 & 309 & 303 & 612 & 859 & 71.25 & 74.28 & 68.40 \\
\hline 7 & 559 & 449 & 1008 & 1284 & 78.50 & 87.07 & 69.94 \\
\hline 8 & 679 & 580 & 1259 & 1638 & 76.86 & 84.35 & 69.63 \\
\hline 9 & 461 & 393 & 854 & 1166 & 73.24 & 81.02 & 65.83 \\
\hline Total & 4921 & 4473 & 9394 & 11513 & 81.59 & 86.52 & 76.79 \\
\hline
\end{tabular}

Source: Census of 2011

\subsubsection{Illiterates}

The total number of illiterate persons in 2011 is 2119 out of this 773 are male and 1352 are female. The highest illiterate in the ward of 6 which is $28.75 \%$ i.e. a big portion of the total population is illiterate of this ward and the lowest illiterates is found in ward number 4 which is $8.55 \%$. The overall illiterate in this Municipality is $18.41 \%$ in 2011. 
Table10: Ward-Wise \% of Illiteracy Rate in Mirik Municipality, 2011

\begin{tabular}{|l|l|l|l|l|l|l|l|}
\hline $\begin{array}{l}\text { Ward } \\
\text { Number }\end{array}$ & $\begin{array}{l}\text { No. of Male } \\
\text { Illiterate }\end{array}$ & $\begin{array}{l}\text { No. of Female } \\
\text { Illiterate }\end{array}$ & $\begin{array}{l}\text { Total } \\
\text { Illiterate }\end{array}$ & $\begin{array}{l}\text { Total } \\
\text { Population }\end{array}$ & $\begin{array}{l}\text { Illiteracy } \\
\text { Rate In \% }\end{array}$ & $\begin{array}{l}\text { \%o } \\
\text { male } \\
\text { illiterate }\end{array}$ & $\begin{array}{l}\text { \% } \\
\text { female } \\
\text { illiterate }\end{array}$ \\
\hline 1 & 67 & 108 & 175 & 904 & 19.36 & 15.26 & 23.23 \\
\hline 2 & 87 & 138 & 225 & 1566 & 14.37 & 11.63 & 16.87 \\
\hline 3 & 94 & 186 & 280 & 1824 & 15.35 & 10.38 & 20.26 \\
\hline 4 & 48 & 64 & 112 & 1310 & 8.55 & 6.65 & 10.88 \\
\hline 5 & 47 & 66 & 113 & 962 & 11.75 & 10.66 & 12.67 \\
\hline 6 & 107 & 140 & 247 & 859 & 28.75 & 25.72 & 31.60 \\
\hline 7 & 89 & 193 & 276 & 1284 & 21.50 & 13.86 & 30.06 \\
\hline 8 & 126 & 253 & 379 & 1638 & 23.14 & 15.65 & 30.37 \\
\hline 9 & 108 & 204 & 312 & 1166 & 26.76 & 18.98 & 34.17 \\
\hline Total & 773 & 1352 & 2119 & 11513 & 18.41 & 13.59 & 23.21 \\
\hline
\end{tabular}

Source: Census of 2001

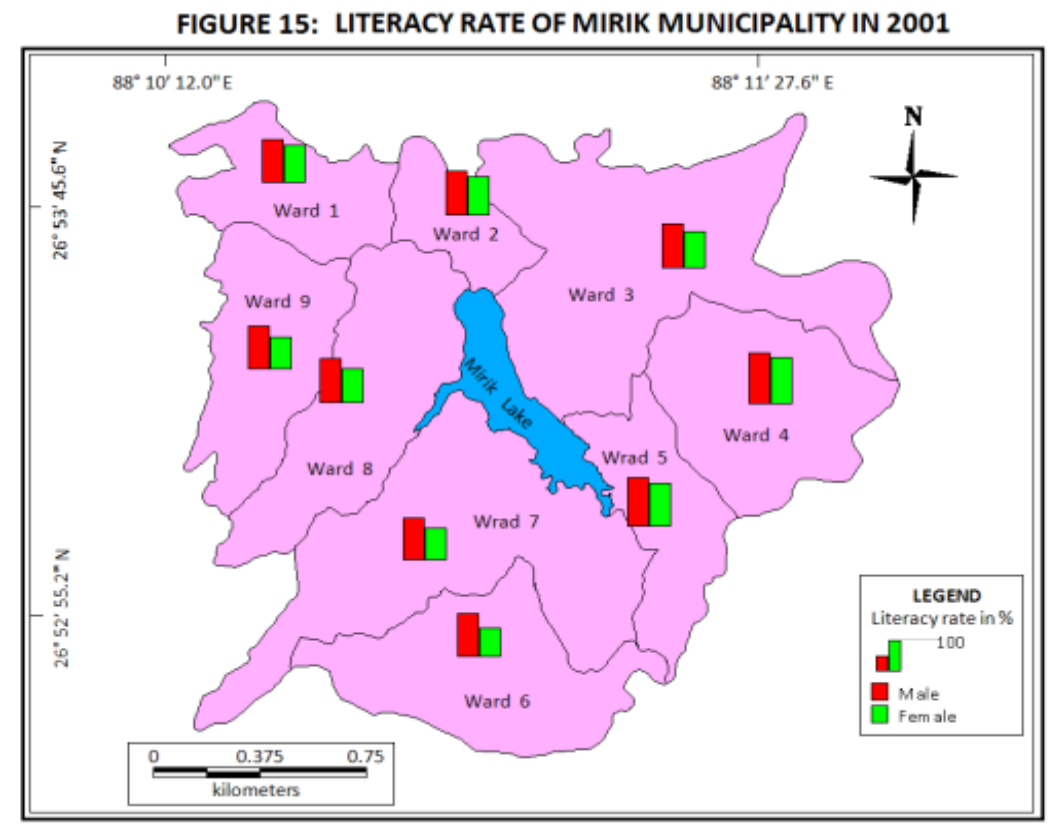

FIGURE 16: LITERACY RATE \& ILLITERATE OF MIRIK MUNICIPALITY IN 2011

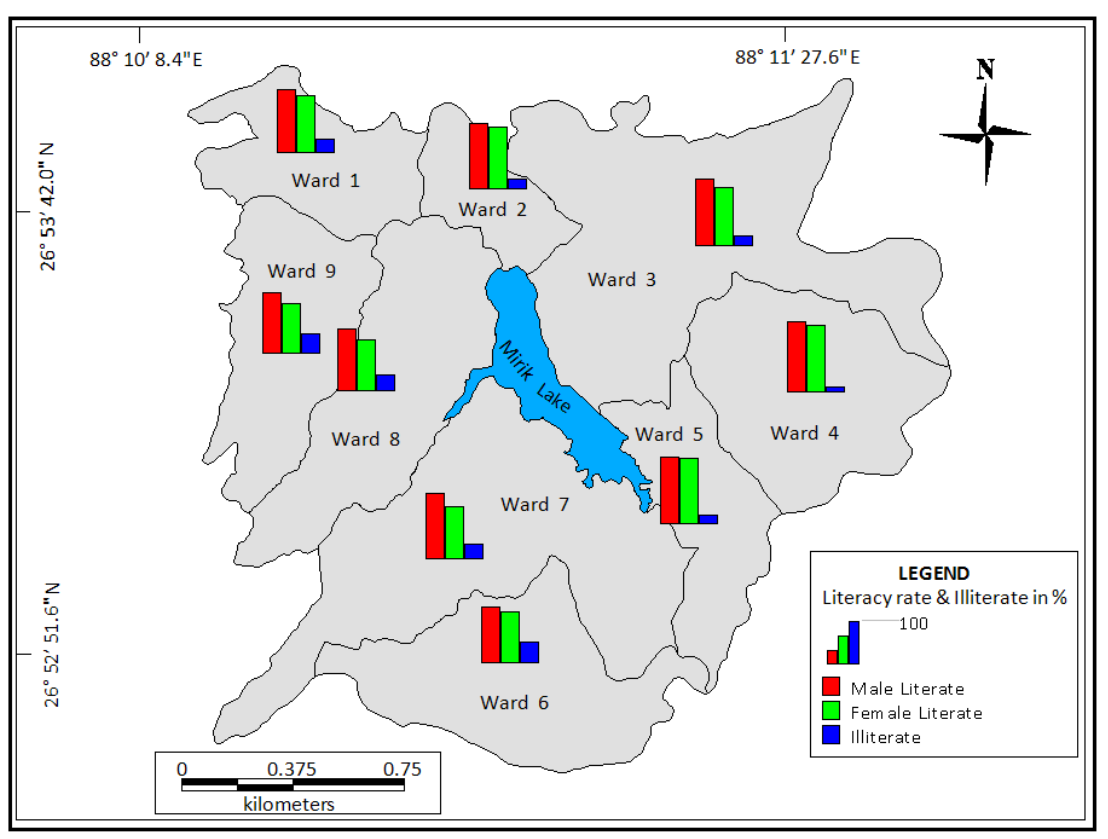

Source: Mirik Municipality 


\subsection{SC \& ST Population}

The study of SC and ST Population in demographic perspective is an important criteria. According to 2001 census the Mirik Municipality had 7.03\% Sc population and 3.33\% St Population. But in 2011, the percentage of Sc population is $6.55 \%$ and $34 \%$ is St Population.

Table11: Ward-Wise Sc Population of Mirik Municipality in 2011

\begin{tabular}{|l|l|l|l|l|l|}
\hline Ward No. & Male & Female & Total Sc population & Total population & \% of Sc population \\
\hline 1 & 17 & 10 & 27 & 904 & 2.99 \\
\hline 2 & 76 & 85 & 161 & 1566 & 10.28 \\
\hline 3 & 82 & 81 & 163 & 1824 & 8.94 \\
\hline 4 & 7 & 6 & 13 & 1310 & 0.99 \\
\hline 5 & 35 & 42 & 77 & 962 & 8.00 \\
\hline 6 & 0 & 0 & 0 & 859 & 0.00 \\
\hline 7 & 51 & 50 & 101 & 1284 & 7.87 \\
\hline 8 & 79 & 82 & 161 & 1638 & 9.83 \\
\hline 9 & 24 & 27 & 51 & 1166 & 4.37 \\
\hline Total & 371 & 383 & 754 & 11513 & 6.55 \\
\hline
\end{tabular}

Source: Census of 2011

Table12: Ward-Wise St Population of Mirik Municipality in 2011

\begin{tabular}{|l|l|l|l|l|l|}
\hline Ward No. & Male & Female & Total St population & Total population & \% of St population \\
\hline 1 & 221 & 247 & 468 & 904 & 51.77 \\
\hline 2 & 193 & 221 & 414 & 1566 & 26.44 \\
\hline 3 & 309 & 320 & 629 & 1824 & 34.48 \\
\hline 4 & 70 & 52 & 122 & 1310 & 9.31 \\
\hline 5 & 120 & 163 & 283 & 962 & 29.42 \\
\hline 6 & 300 & 316 & 616 & 859 & 71.71 \\
\hline 7 & 274 & 277 & 551 & 1284 & 42.91 \\
\hline 8 & 150 & 158 & 308 & 1638 & 18.80 \\
\hline 9 & 251 & 268 & 519 & 1166 & 44.51 \\
\hline Total & 1888 & 2022 & 3910 & 11513 & 33.96 \\
\hline
\end{tabular}

Source: Census of 2011

In 2001, the highest Sc population was found in ward number 2 which is $10.28 \%$, followed by ward number $8(9.83 \%), 3(8.94 \%), 5(8 \%), 7(7.87 \%)$ and the lowest is found in ward number 6 which is nil or $0.0 \%$. similarly, the highest St population was found in ward number 6 which is $71.71 \%$, followed by ward number $1(51.77 \%), 9(44.51 \%), 7(42.91 \%)$ and the lowest \% of St population found in ward number 4 which is $9.31 \%$. So, from the above data we can easily understand that the Mirik Municipality had a large portion of St Population. Though 2001 census data shows that the total number of St Population was 303 (3.33\%) but in 2011, the total number of St Population has increased in a significant manner to $3910(33.96 \%)$.

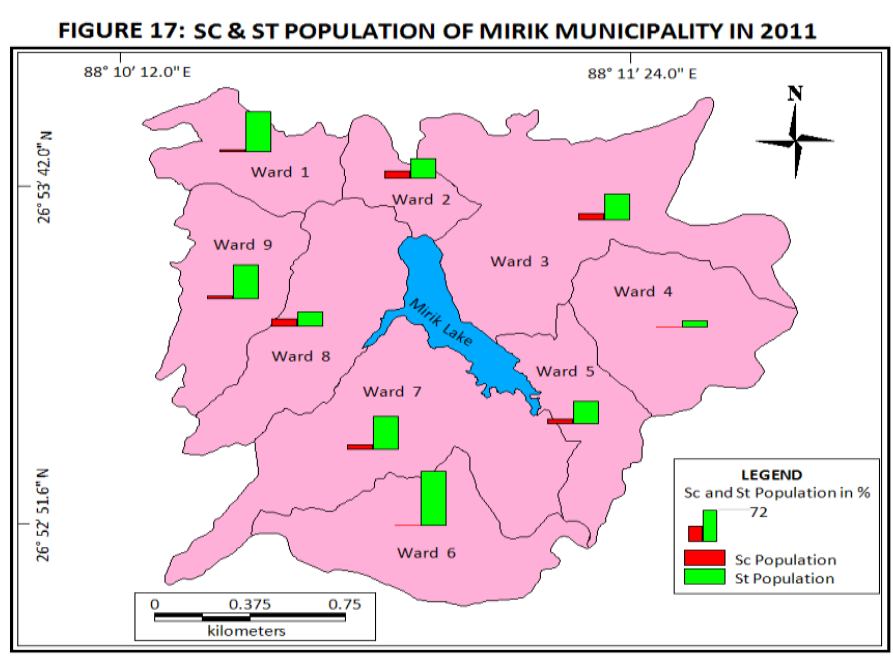

Source: Mirik Municipality 


\subsection{BPL Population}

According to SUDA survey 2006, there were 830 BPL household in Mirik Municipality which make average $42.96 \%$ of BPL population in this town. The highest BPL household was found in ward number 8 which was 222 and the lowest was in ward number 5 which was 3 . But the highest BPL \% was found in ward number 6 which was $83 \%$ and the lowest is in the ward number 5 which was $2 \%$.

Table13: Ward-Wise Bpl Population of Mirik Municipality in 2006

\begin{tabular}{|l|l|l|l|l|l|}
\hline Ward No & Total Population & Total BPL Population & Total Household & Total BPL Household & $\%$ of BPL \\
\hline 1 & 994 & 467 & 173 & 82 & 47 \\
\hline 2 & 1113 & 245 & 193 & 42 & 22 \\
\hline 3 & 1354 & 203 & 249 & 37 & 15 \\
\hline 4 & 979 & 147 & 228 & 52 & 15 \\
\hline 5 & 765 & 15 & 139 & 3 & 2 \\
\hline 6 & 877 & 728 & 162 & 134 & 83 \\
\hline 7 & 1178 & 624 & 254 & 135 & 53 \\
\hline 8 & 1657 & 1160 & 316 & 222 & 70 \\
\hline 9 & 1050 & 693 & 187 & 123 & 66 \\
\hline Total & 9967 & 4282 & 1901 & 830 & 42.96 \\
\hline
\end{tabular}

Source: SUDA Survey, 2006

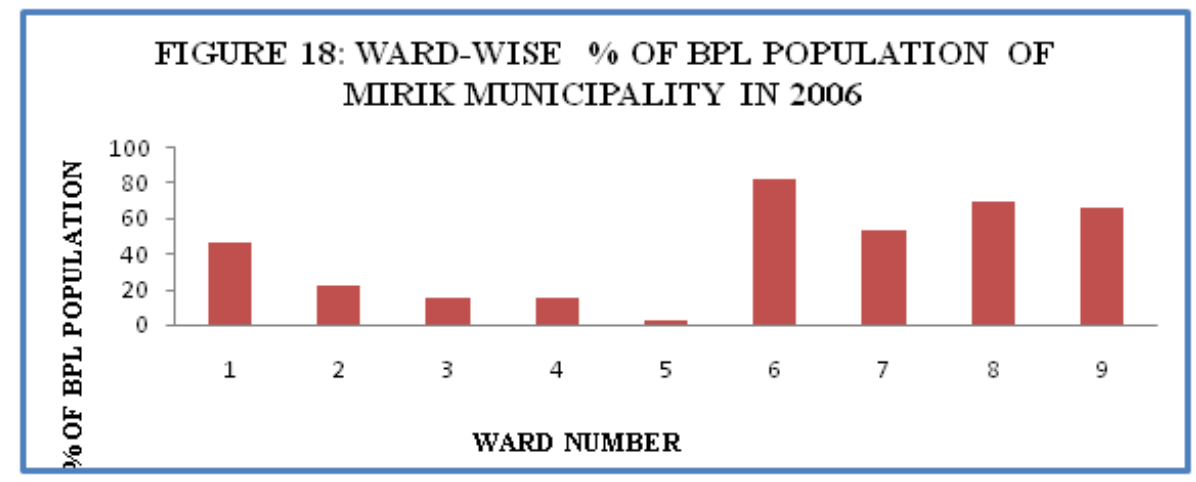

\subsection{Religion Structure}

According to Mirik population census 2011, it was found that $55.51 \%$ of population are Hindus, $1.35 \%$ are Muslims, $4.87 \%$ are Cristians, $0.17 \%$ are Sikh, $35.40 \%$ are Buddhist etc. So a major portion of population belong to Hindu community.

Table14: Percentage of Different Religions Population in Mirik Municipality, 2011

\begin{tabular}{|l|l|l|l|l|l|l|l|l|}
\hline Religions & Hindu & Muslim & Christian & Sikh & Buddist & Jain & others & Not Stated \\
\hline Population in \% & 55.15 & 1.35 & 4.87 & 0.17 & 35.40 & 0.05 & 2.36 & 0.28 \\
\hline
\end{tabular}

Source: Cenus of 2011

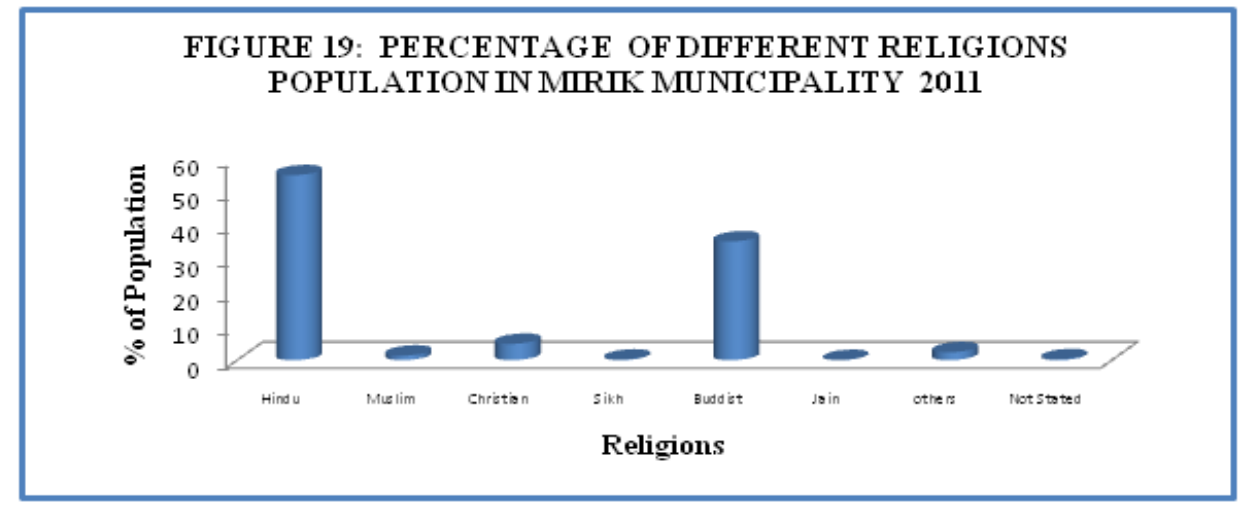

\subsection{Slum Population}

\subsubsection{Defination of Urban Slum}

The definition of a slum in an urban area generally differs within various countries, states and even cities. Recent research has also indicated that slums may be more heterogeneous than is often 
assumed (Goli et al., 2011, Chandrasekhar and Montgomery, 2009, Agarwal and Taneja, 2005); many poor people like pavement dwellers do not live in slums and are therefore not "counted" by the standard definitions (Agarwal, 2011).

The United Nations operationally defines a slum as "one or a group of individuals living under the same roof in an urban area, lacking in one or more of the following five amenities": 1) Durable housing (a permanent structure providing protection from extreme climatic conditions); 2) Sufficient living area (no more than three people sharing a room); 3) Access to improved water (water that is sufficient, affordable, and can be obtained without extreme effort); 4) Access to improved sanitation facilities (a private toilet, or a public one shared with a reasonable number of people); and 5) Secure tenure (de facto or de jure secure tenure status and protection against forced eviction) (UNHABITAT, 2006/7).

Slum is a part of urbanization. In 2011, each of the 9 ward had a slum population. 4082 persons constitute slum population in Mirik Municipality which is $35.46 \%$ of the total population. The highest slum population was found in ward number ?, followed by ward number ? and the lowest was found in ward number? . But the biggest slum is ?, followed by ?. The slum area are the home of drivers, cobbler, sweepers etc living in an unhygienic environment. The Mirik Municipality had shown large portion of slum in their own survey book in a purpose to sanction a large amount for the development of the town.

Table15: Slum Population of Mirik Municipality in 2011

\begin{tabular}{|l|l|l|l|}
\hline Ward No. & Slum Name & Total Slum Population & \% of Slum Population \\
\hline 1 & Nize Gaon & 450 & 54.15 \\
\hline & Upper Mirik Busty & 400 & \multirow{2}{*}{28.15} \\
\hline 3 & Thanaline Busty & 300 & \\
\hline & Rato Matay Busty & 360 & 45.34 \\
\hline 4 & Upper Deosey Dara & 350 & 59.03 \\
\hline 6 & Upper Kawley Busty & 425 & 50.87 \\
\hline 7 & Rasdal Gaon & 525 & 59.06 \\
\hline 9 & Mahendra Gaon & 750 & 47.89 \\
\hline
\end{tabular}

Source: Draft Development Plan of Mirik Municipality, 2008-2013

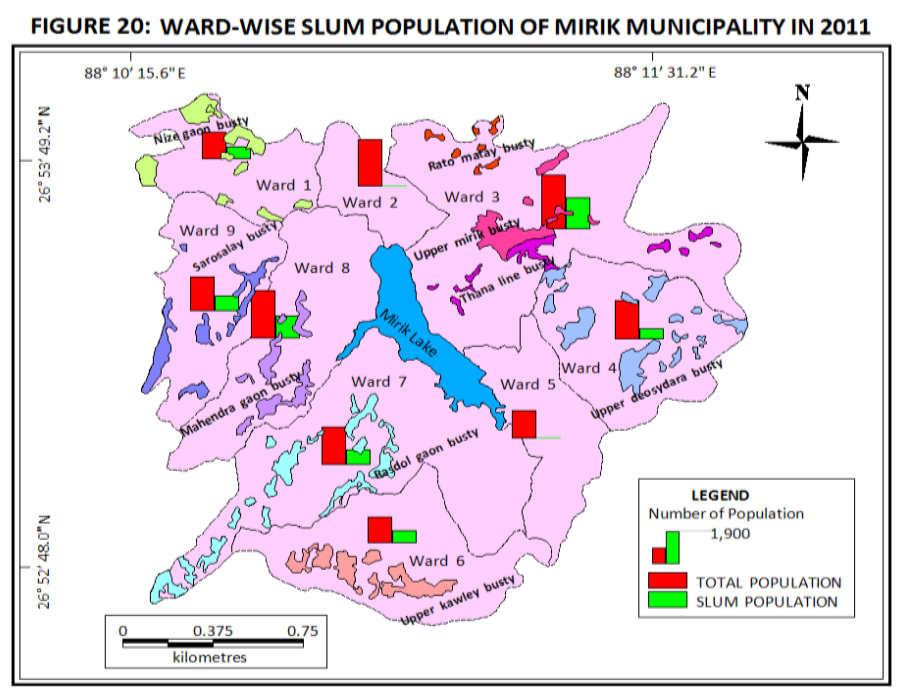

Source: Mirik Municipality

\subsection{Maritial Status}

A Sample Survey on Mirik Municipality shows that $56.63 \%$ are the married population (out of this $51.06 \%$ are male and $48.94 \%$ are female) and $43.37 \%$ are unmarried population $(52.77 \%$ are male and $47.23 \%$ are female) of this town.

\section{Problems Identification Related to the demography on the Mirik Municipality}

The area has human resources for economic and tourist industrial growth. At present it is a moderate type of tourist spot as there are different problems of the Municipality. The problems are as below- 
- Inadequate Public Health Services: Absence of specialized departments in the Hospitals with no provision of ICU. Absence of Morgue and Hearse Car in the hospitals. Fringe area people are not fully under the health care facilities. There exists only one community based primary health centre in the municipality.

- Inadequate Reproductive and Child Health Care: There is no RCH in the municipal area and inadequate supply of immunization kits and problems of its preservation.

- Water problem: Water is main problem in any hill area. Also this Municipality has acute water scarcity. Most of the inhabitants either drink water from tube well, Jhoras or needs to buy water from Private sector but this turns out to be too expensive for them. In spite of this, most of the Jhoras dry up during the summer season. Besides this, the water quality of Mirik Lake is also polluted now.

- Lack of Job Opportunities: There is not much Private sector. So jobs are limited.

- Lack of Education Institutions: There is no Medical College or no Engineering College, only one arts college (Mirik College). So to get higher education and better Medical facility people and students are forced to migrate to other places.

- Lack of Roads and Transportation: Roads are very narrow in terms of communication due to hilly terrain and the number of Vehicles are also very less. As a result the transportation cost is very high. Though, there is a helipad but that is unused.

- Poor Drainage Systems: In this area, the drainage system is very poor. Most of the drains are Kutcha and narrow. So during excessive rainfall the water over flows on the roads and creates an unmanageable condition.

- Slums: Slums are growing rapidly day by day and they destroy the natural scenic beauty of the town as they live in an unhygienic condition.

\section{SugGeSTIVE MEASURES RELATED TO DEMOGRAPHY FOR MIRIK MUNICIPALITY}

- Plan-wise settlements: Mirik Municipality has been suffering very much due to unplanned settlements. It demands for more improved and planned housing.

- Tourism base economy: As it is tourist place, if the new tourism industry comes in, then the whole economy will be changed.

- Better infrastructural facility on Hospital: the present condition of hospitals calls for developed infrastructural facilities to get better treatment and establishment of $\mathrm{RCH}$ in the Municipal area.

- P.H.E Water: Municipality have to give the water for 2or 3 times in a day and for that purpose Municipality have to utilize the Lake and Jhoras water as it is a potential resource.

- Solid Waste collection: Municipality has to collect the waste from the inhabitants regularly and finally utilize those wastes.

- Developed Transportation facility: In terms of Transportation, roads are needed to be made wider so that accessibility gets better. Rail services are not available here. So, if the Rail or Toy Train can run over the Mirik town then it will be more valuable tourist place in comparison to others tourist spot and make a mark on the map of India

\section{CONClusion}

Mirik Municipality has a great importance since the ancient period of the West Bengal. This Municipality has a historical background and has variety in demographic features. This town has a high increasing rate of trade and economic activity which is mainly based on tourism. Although this area has several problems but the town has great future possibilities for expansion. So at the end, it may be concluded that an ethical and encouraging Govt. policy and a good co-relation among the Govt. and local people can solve most of the problems in this Municipality. 


\section{ACKNOWLEDGEMENT}

I would like to express my sincere thanks to Dr. Indira Lepcha (nee) Lama (Associate Professor), Department of Geography \& Applied Geography, University of North Bengal for guiding me to complete my paper.

\section{REFERENCES}

[1] Agarwal Siddharth \& Taneja Shivani (2005) : All slums are not equal: child health conditions among the urban poor in Indian Pediatrics 42 (Online), pp:233-244.

[2] Bhende, A.A \& Kanitkar, T (2010) : Principles of Population Studies, Himalaya Publishing House, Mumbai, ISBN 978-93-5024-668-9, pp. 622-626.

[3] Census of India (2011) : District Census Handbook Darjeeling, Directorate of Census Operations, West Bengal, Series- 20, Part XII-B, pp. 9-16 \& pp. 36-41.

[4] Chandna, R.C (2000) : Regional Planning and Development, Kaltani Publishers, New Delhi, ISBN 97893-272-4141-9, pp. 294-297.

[5] Chandna, R.C. (2015) : Geography of Populations : Concepts Determinants and Patterns, Kalyani Publishers, New Delhi, ISBN 978-93-272-3647-7, pp. 407-411.

[6] Chandrasekhar S \& Montgomery Mark R (2010) : Broadening Poverty Definitions in India: Basic needs and urban housing. (Online), pp 5-7.

[7] Gallion, Aurther B. \& Eisner, Simon (2005) : The Urban Pattern city planning and design, J.S. Offset Printers, Delhi, ISBN 81-239-0915-2, pp. 263-286.

[8] Hudson, F.S (1981) : A Geography of Settlements, Macdonald \& Evans Ltd., U.K, ISBN 0-7121-0726, pp. 267-286.

[9] Khullar, D.R. (2014) : India A Comprehensive Geography, Kalyani Publishers, New Delhi, ISBN 978-93272-4674-2, pp. 369-376 \& pp .403-411.

[10] Mandal, R.B (2000) : Urban Geography A textbook, Concept Publishing Company, New Delhi, ISBN 817022-795-X, pp. 479-489.

[11] Misra, R.P (2002) : Regional Planning- concepts, techniques, policies and case studies, Concept Publishing Company, New Delhi, ISBN 81-7022-494-2, pp.795-799.

[12] Northam, R.M (1979) : Urban Geography, John Wiley \& Sons, New York, ISBN 0-171-03292-1, pp. 467476.

[13] Ramachandran, R (2015) : Urbanization and Urban Systems in India, Rakmo Press, New Delhi, ISBN 978-0-19-562959-0, pp. 317-320 \& pp. 342-347.

[14] Sharma, K.L (2008) : Indian Social Structure and Change, Rawat Publications, New Delhi, ISBN 81-3160083-1, pp. 275-280.

[15] Sidhartha, K. \& Mukherjee, S. (2000) : Cities, Urbanisation \& Urban Systems (Settlement Geography), Kitab Mahal Printing Division, Allahabad, ISBN 978-81-225-0817-8, pp. 357-282.

[16] https://en.wikipedia.org/wiki/Mirik (accessed on 18th January 2018).

[17] https://www.victoriapark.wa.gov.au/About-Council/Who-are-we/Demographics-and-statistics (Accessed on 20th January 2018)

[18] http://shodhganga.inflibnet.ac.in/bitstream/10603/149403/8/08_chapter_03.pdf (Accessed on 22 January 2018)

[19] http://www.business-standard.com/article/news-ians/the-changing-demographics-in-north-bengal-s-teaestates-115042100458_1.html (Accessed on 27th January 2018). 


\section{AUTHOR'S BIOGRAPHY}

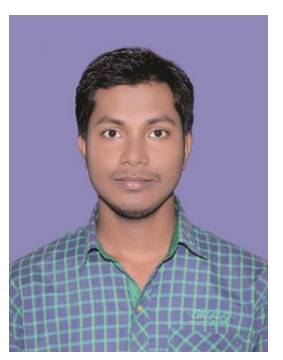

Name of the Author: Ershad Ali

Date of Birth: 12/02/1994

Address: Village- Harir Bari, P.O- Garal Bari, Dist- Jalpaiguri, PIN- 735132, West Bengal, India.

Email: aliershad.geo@gmail.com

Contact Number: +91 8967252423

Education: M.A in Geography and Applied Geography from the University of North Bengal in 2016.

Area of Specialization: Urban Geography, Population Geography.

Present Position: Guest Lecturer in Geography at Ananda Chandra College, Jalpaiguri, West Bengal, India.

Citation: Ershad Ali. Demographic Characteristics of Mirik Municipality with Reference to 2001 \& 2011 Census Data. International Journal of Research in Geography. vol 4, no. 1, 2018, pp. 50-66. doi:http://dx.doi. org/10.20431/2454-8685.0401008.

Copyright: (C) 2018 Authors. This is an open-access article distributed under the terms of the Creative Commons Attribution License, which permits unrestricted use, distribution, and reproduction in any medium, provided the original author and source are credited. 